Article

\title{
Abundance of Biological Ice Nucleating Particles in the Mississippi and Its Major Tributaries
}

\author{
Bruce F. Moffett ${ }^{1, *}$, Tom C. J. Hill ${ }^{2}$ and Paul J. DeMott ${ }^{2}$ (D) \\ 1 Ocean Lab, The Parrog, Fishguard Harbour, Wales SA64 0ED, UK \\ 2 Department of Atmospheric Science, Colorado State University, Fort Collins, CO 80523, USA; \\ Thomas.Hill@colostate.edu (T.C.J.H.); Paul.Demott@colostate.edu (P.J.D.) \\ * Correspondence: b.f.moffett@gmail.com
}

Received: 10 July 2018; Accepted: 3 August 2018; Published: 7 August 2018

\begin{abstract}
Ice nucleating particles (INPs) are rare among atmospheric aerosols. However, through their ability to induce freezing of cloud droplets in cold clouds, they affect cloud lifetime, cloud albedo, and the efficiency and distribution of precipitation. While terrestrial sources of INPs are the focus of much research, the potential of rivers and lakes to be significant INP reservoirs has been neglected. In the first survey of a major river system, surface waters from the Mississippi, Missouri, Platte, and Sweetwater Rivers, all draining east and south from the Great Divide in the United States of America (USA), were tested for their INP concentrations. The survey comprised 49 samples, taken approximately every 150-250 km along 90\% of the Mississippi (from Natchez, MS to the source at Bemidji, MN), the full length of the Missouri, $90 \%$ of the North Platte, and all of the Sweetwater. Samples were analysed using the immersion freezing method. The highest freezing temperature varied between -4 and $-6{ }^{\circ} \mathrm{C}$, and the concentration of INPs active at $-10^{\circ} \mathrm{C}$ or warmer ranged from 87 to $47,000 \mathrm{~mL}^{-1}$. The average INP concentration at $-10^{\circ} \mathrm{C}$ was $4950 \mathrm{~mL}^{-1}$, almost four orders of magnitude greater than the numbers of INPs typically found active at this temperature in seawater. The majority of INPs ( 69 to $>99 \%$ ) were heat labile (deactivated by heating to $95^{\circ} \mathrm{C}$ ) and therefore likely to be biological. Although the surface area of rivers is limited, their significant concentrations of INPs suggest that freshwater emissions should be investigated for their potential impact on regional cloud processes.
\end{abstract}

Keywords: ice nucleating particles; Mississippi; Missouri; Platte; rivers; freshwater; regional atmospheric dynamics

\section{Introduction}

Ice nucleating particles (INPs) form only a very small subset of all aerosols in the atmosphere [1]. Even so, warmer than about $-38{ }^{\circ} \mathrm{C}$, INPs are required to catalyse the formation of ice crystals in clouds in a process termed heterogeneous nucleation. Colder than $-38{ }^{\circ} \mathrm{C}$, INPs are not required, and this is termed homogenous freezing. The action of the INPs greatly influences the distribution of liquid and ice particles within clouds. They thereby exert a potentially strong modulation of Earth's energy budget and the water cycle through their modification of cloud radiative properties, the release of latent heat, and the efficiency and distribution of precipitation [2-5].

Terrestrial sources of INPs have received much attention. In addition to ongoing interest into the action of both mineral dusts and soot [6-8], the role of the soil organic matter, which includes INPs produced by the decomposer community, as a source of atmospheric INPs is now being more closely examined [9-12]; pioneering work identified the litter layer, in particular, as a prodigious source of biological INPs in diverse global ecotypes [13,14]. By contrast, while oceans comprise $71 \%$ of the Earth's surface area and emit INPs within sea spray - mainly by bubble bursting - they 
are only now being investigated more systematically [15-21]. Until recently, the only systematic study of INPs in the marine boundary layer was that undertaken by Bigg [22]. Low INP levels over oceans and variable production of biological INPs has recently been documented in marine sea spray aerosol $[18,23]$, and higher levels appear to be generated by planktonic blooms or the ensuing microbial succession $[16,18,19,24,25]$. Their emission from the ocean surface will likely be enhanced by their enrichment in the sea surface microlayer $[17,26]$.

Freshwaters as sources of INPs have been largely overlooked. Morris et al. [27,28] showed cultivable Pseudomonas syringae were present in a variety of fresh water habitats at 0.05 to $10 \mathrm{~mL}^{-1}$, with most characterised as ice nucleation active. In addition, diatoms thought to be associated with ice nucleating bacteria in lake water were shown to produce ice at up to $-3^{\circ} \mathrm{C}$ [29]. Pietsch et al. [30] investigated the aerosolisation of two strains of Pseudomonas in a Collison nebuliser; air was injected at high velocity through the nebulizer's orifice which broke the cell suspension apart into small droplets. More recently, two studies have measured INPs in river surface waters. Moffett [31] surveyed the river Gwuan from its upper reaches to several kilometres out to sea for total and heat sensitive INP concentrations, while Larsen et al. [32] measured INPs weekly at one position in the Rhine, in Basel, Switzerland, over 16 months. Baseline Rhine river concentrations were $<100$ INPs active at $-8{ }^{\circ} \mathrm{C} \mathrm{mL}^{-1}$, but this increased to around $4000 \mathrm{INPs} \mathrm{mL}^{-1}$ at $-8{ }^{\circ} \mathrm{C}$ during transitory peak flows following intense rainfall, likely associated with the flushing of INPs from plant surfaces, litter, and soil. Most INPs were small $(<0.22 \mu \mathrm{m})$.

The work documented here is the first analysis of INPs in a major river system. We demonstrate that the river waters contained high levels of biological INPs and suggest that their potential influence on cold cloud ice formation and precipitation requires investigation.

\section{Materials and Methods}

A single surface water sample was taken approximately every $150-250 \mathrm{~km}$ along the river systems (Figure 1). To sample river surface water, a sterile $15 \mathrm{~mL}$ centrifuge tube (Falcon, VWR, Lutterworth, UK) was taped to a $4 \mathrm{~m}$ length of plastic pipe. The assembly was then lowered into the water as vertically as possible and the top $\sim 1 \mathrm{~cm}$ of water allowed to flow into the tube. These samples were then immediately frozen on dry ice for a maximum of $48 \mathrm{~h}$ or kept cold on crushed ice for at most $6 \mathrm{~h}$ before analysis. A second bulk sample of approximately $450 \mathrm{~mL}$ was then taken in the same way into a clean $500 \mathrm{~mL}$ polypropylene bottle (VWR), and within $5 \mathrm{~min}$ the temperature and $\mathrm{pH}$ determined. The $\mathrm{pH}$ was determined using a portable meter checked every day with standard buffers. INPs were counted using a thermal cycler, (PTC-200, MJ Research, Watford, UK) as described in Hill et al. [33], except in this case the thermal cycler had been modified to enable cooling to $30{ }^{\circ} \mathrm{C}$ below ambient. INP determinations were performed using 16-24 aliquots of 80-100 $\mu \mathrm{L}$ in a single-use 96-well polypropylene plate (Starlab, Milton Keynes, UK). The temperature was reduced in increments of $1{ }^{\circ} \mathrm{C}$ with a transition time of $5-10 \mathrm{~s}$. Samples were then held for $2 \mathrm{~min}$ at each temperature before assessing the number of frozen wells visually. Conversion to INP $\mathrm{mL}^{-1}$ water at each temperature was estimated using the formula $-\ln (f) / V$, where $f$ is the proportion of droplets not frozen and $V$ is the volume of each aliquot [34]. The majority of samples were also heated in the modified thermal cycler to $95{ }^{\circ} \mathrm{C}$ for $20 \mathrm{~min}$. Before reanalysis to determine the fraction of INPs which were likely to be biological, the trays were briefly centrifuged to remove small bubbles (these can obscure the appearance of freezing). Three pooled samples and one individual sample were also filtered through $0.22 \mu \mathrm{m}$-pore-diameter syringe filters (PES, VWR) to gauge the size of the INPs. The syringe filters contributed no INPs to the samples. Deionised water passed through a $20 \mathrm{~nm}$ filter served as controls in each determination ( $0.6 \%$ of control wells froze during these experiments).

The results for 49 samples are presented. The majority were sampled in a two-week period in June 2015 and the remainder in a two-week period in September 2012. One site (Lewellen, NE, USA) was sampled on both occasions. 


\section{Results}

Sampling locations and numbers of INPs active at $-10^{\circ} \mathrm{C}$ or warmer are shown in Figure 1 , whereas details of sampling location, water chemistry, and INP concentrations at $-7{ }^{\circ} \mathrm{C}$ and $-10^{\circ} \mathrm{C}$, as well as the $\%$ heat labile at $-10^{\circ} \mathrm{C}$, are shown in Table 1 . Water temperatures varied from 11.0 to $28.6^{\circ} \mathrm{C}$, while $\mathrm{pH}$ ranged from 6.8 to 9.0 .

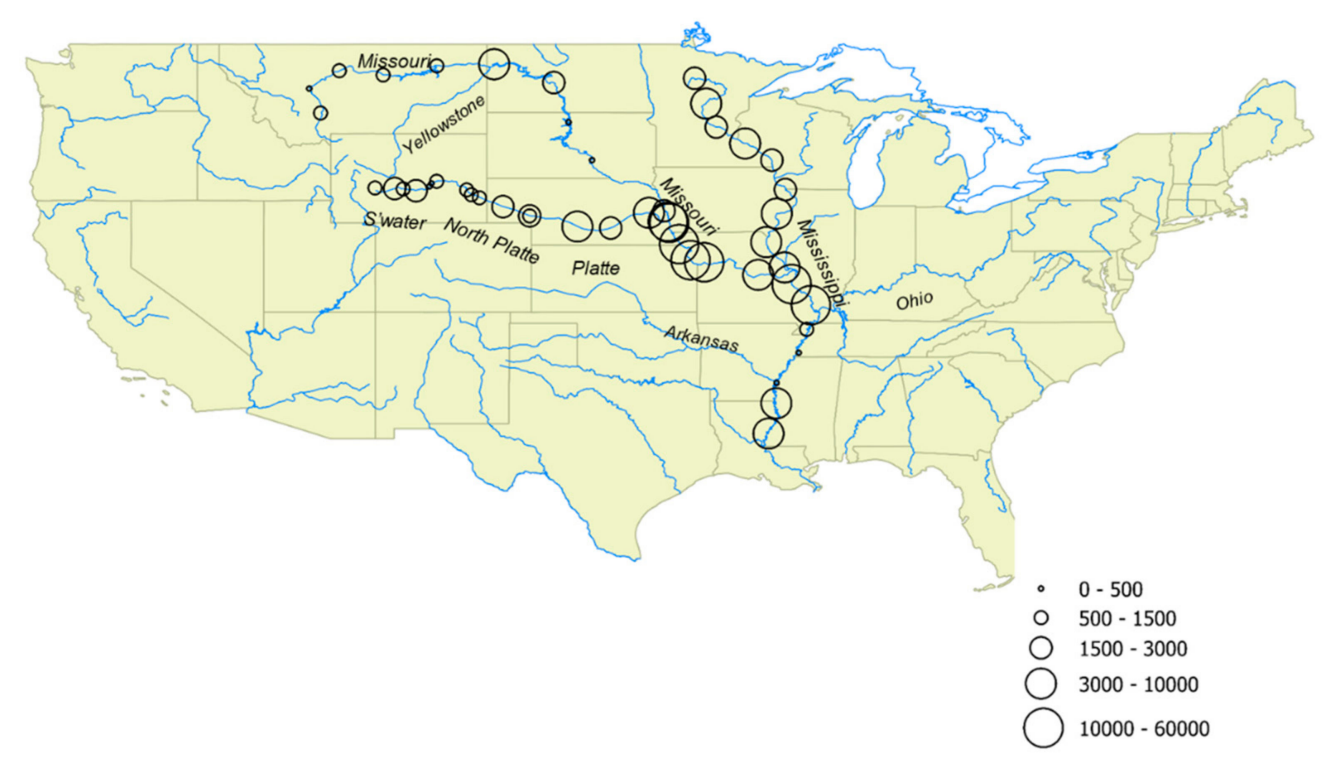

Figure 1. Sampling locations and ice nucleating particle concentrations (per millilitre active at $-10{ }^{\circ} \mathrm{C}$ ).

Ice spectra (the number of INPs per $\mathrm{mL}$ plotted against temperature) are shown for both untreated and selected heat treated $\left(95{ }^{\circ} \mathrm{C}\right)$ samples separately for the Mississippi, Missouri, and Sweetwater/Platte Rivers in Figure 2 (complete results for heat treated samples are shown in Figure S1). The most efficient INPs initiated freezing at between -4 and $-6{ }^{\circ} \mathrm{C}$, while numbers active at -7 and $-10{ }^{\circ} \mathrm{C}$ or warmer ranged from 36 to $12,000 \mathrm{~mL}^{-1}$ and 87 to $47,000 \mathrm{~mL}^{-1}$ river water, respectively (Table 1). In precipitation, the corresponding values mostly fall within the range 0.1 to $50 \mathrm{~mL}^{-1}$ [1]. Hence, direct inputs to rivers from precipitation (apart from that which intersects foliage) is a minor source. Heating reduced INP concentrations, typically to the limit of testing at -13 to $-15{ }^{\circ} \mathrm{C}$. At $-10{ }^{\circ} \mathrm{C}$ or warmer, 66 to $>99 \%$ of INPs were heat labile, and therefore likely to be biological [13] (Table 1).

Three samples from the 2012 campaign were filtered using $0.22 \mu \mathrm{m}$ disposable filters. As shown in Table 2, the proportion of INPs in the filtrate was variable. Between 24 and $>99 \%$ of INPs passed through the filters, suggesting that a significant proportion were not intact cells. 
Table 1. Details of sampling locations and ice nucleating particle concentrations. SAREC $=$ Sustainable Agriculture Research and Extension Centre.

\begin{tabular}{|c|c|c|c|c|c|c|c|c|c|c|}
\hline River & Location & Date & Lat. & Long. & $\begin{array}{l}\text { Water Temp. } \\
\quad\left({ }^{\circ} \mathrm{C}\right)\end{array}$ & $\mathrm{pH}$ & $\begin{array}{c}\text { Onset of } \\
\text { Freezing }\left({ }^{\circ} \mathrm{C}\right)\end{array}$ & $\begin{array}{l}\text { INPs Active at } \\
-7^{\circ} \mathrm{C}\left(\mathrm{mL}^{-1}\right)\end{array}$ & $\begin{array}{l}\text { INPs Active at } \\
-10^{\circ} \mathrm{C}\left(\mathrm{mL}^{-1}\right)\end{array}$ & $\begin{array}{l}\text { INPs Heat Labile } \\
\text { at }-10^{\circ} \mathrm{C}(\%)\end{array}$ \\
\hline Sweetwater & Sweetwater Camp Site & $8 / 15 / 2012$ & 42.564837 & -109.061902 & 11.0 & 6.8 & -5 & 43 & 690 & 81 \\
\hline Sweetwater & Sweetwater Bridge & $8 / 15 / 2012$ & 42.541721 & -108.18018 & 17.0 & 7.7 & -6 & 180 & 1600 & 99 \\
\hline Sweetwater & Ore Road & $8 / 15 / 2012$ & 42.524983 & -107.798983 & 21.0 & 8.0 & -6 & 130 & 1200 & 66 \\
\hline Sweetwater & Mormon Bridge & 8/14/2012 & 42.442715 & -107.221725 & - & - & -5 & 420 & 2100 & 78 \\
\hline North Platte & Miles Landing & $8 / 16 / 2012$ & 42.638502 & -106.619033 & 17.0 & 7.3 & -6 & $>69$ & 130 & 67 \\
\hline North Platte & Bessemer Bend Rd & $8 / 16 / 2012$ & 42.771948 & -106.530563 & 17.0 & 7.7 & -5 & $>69$ & 87 & 89 \\
\hline North Platte & Pacificorp, Casper & $8 / 16 / 2012$ & 42.865464 & -106.297231 & 19.0 & 8.4 & -4 & 87 & 540 & 76 \\
\hline North Platte & Glendo Dam & 8/17/2012 & 42.478084 & -104.951656 & 17.0 & 7.3 & -4 & 370 & 1100 & 66 \\
\hline North Platte & Guernsey & $8 / 17 / 2012$ & 42.259881 & -104.74157 & 20.0 & 8.6 & -5 & 370 & 1500 & 75 \\
\hline North Platte & SAREC, Lingle & $8 / 23 / 2012$ & 42.125186 & -104.378219 & 19.0 & 7.6 & -5 & 340 & 1400 & 87 \\
\hline North Platte & Chimney Rock & $8 / 24 / 2012$ & 41.729665 & -103.324214 & 18.0 & 7.5 & -5 & 410 & 1800 & 95 \\
\hline North Platte & Lewellen & $8 / 24 / 2012$ & 41.316284 & -102.126333 & 21.0 & 7.5 & -5 & 130 & 980 & 91 \\
\hline North Platte & Lewellen & $6 / 14 / 2015$ & 41.316284 & -102.126333 & 21.5 & 8.0 & -4 & 1500 & 2600 & 69 \\
\hline Platte & Cozad & $6 / 14 / 2015$ & 40.837433 & -99.98696 & 22.5 & 8.0 & -5 & 1500 & 4700 & 99 \\
\hline Platte & Hastings & $6 / 14 / 2015$ & 40.77126 & -98.492202 & 24.0 & 8.1 & -5 & 1500 & 1700 & 94 \\
\hline Platte & North Bend & $6 / 14 / 2015$ & 41.452678 & -96.776912 & 24.5 & 8.3 & -5 & 1200 & 4700 & 97 \\
\hline Platte & La Platte & $6 / 15 / 2015$ & 41.058924 & -95.928276 & - & - & -5 & 4700 & 15,000 & 88 \\
\hline Missouri & Three Forks/Headwaters St. Pk. & $6 / 28 / 2015$ & 45.926835 & -111.50578 & 22.1 & 8.6 & -6 & 47 & 590 & - \\
\hline Missouri & Wolf Creek Br./Holter Dam & $6 / 27 / 2015$ & 47.020074 & -112.011922 & 17.3 & 9.0 & -6 & 36 & 170 & - \\
\hline Missouri & Old Fort Benton & $6 / 27 / 2015$ & 47.820359 & -110.663314 & 24.3 & 8.9 & -4 & 350 & 590 & - \\
\hline Missouri & James Kipp Recreation Area & $6 / 27 / 2015$ & 47.627895 & -108.697475 & 27.5 & 8.8 & -5 & 81 & 590 & - \\
\hline Missouri & Fort Peck & $6 / 26 / 2015$ & 48.039842 & -106.290658 & 12.9 & 8.3 & -5 & 870 & 1500 & - \\
\hline Missouri & Williston & $6 / 26 / 2015$ & 48.110958 & -103.717126 & 21.5 & 8.1 & -4 & 2600 & 10,000 & - \\
\hline Missouri & Washburn & $6 / 26 / 2015$ & 47.288804 & -101.042415 & 11.0 & 8.4 & -5 & 470 & 2100 & - \\
\hline Missouri & Mobridge & $6 / 25 / 2015$ & 45.512826 & -100.382602 & 24.2 & 7.3 & -5 & 170 & 360 & - \\
\hline Missouri & Bad River near Fort Pierre & $6 / 25 / 2015$ & 44.353082 & -100.369376 & 23.2 & 7.8 & -5 & 17,000 & 59,000 & - \\
\hline Missouri & Chamberlain & $6 / 25 / 2015$ & 43.815016 & -99.326346 & 21.3 & 8.5 & -5 & 170 & 470 & - \\
\hline Missouri & Blair & $6 / 14 / 2015$ & 41.548381 & -96.097105 & 22.3 & 8.4 & -4 & 1500 & 3000 & 90 \\
\hline Missouri & Plattsmouth & $6 / 15 / 2015$ & 41.000821 & -95.866735 & 23.2 & 7.9 & -4 & 3500 & 12,000 & 95 \\
\hline Missouri & Rulo & $6 / 15 / 2015$ & 40.049925 & -95.421274 & 23.0 & 7.9 & -5 & 4700 & 15,000 & 93 \\
\hline Missouri & Leavenworth & $6 / 15 / 2015$ & 39.330756 & -94.910311 & 23.5 & 7.7 & -4 & 7200 & 26,000 & 95 \\
\hline Missouri & Missouri City & $6 / 15 / 2015$ & 39.236795 & -94.29664 & 22.7 & 7.7 & -4 & 12,000 & 47,000 & 95 \\
\hline Missouri & Mokane & $6 / 17 / 2015$ & 38.670188 & -91.874438 & 20.8 & 7.9 & -5 & 1000 & 3600 & 90 \\
\hline Mississippi & Bemidji & $6 / 23 / 2015$ & 47.483244 & -94.727823 & 20.3 & 8.0 & -6 & 1000 & 1700 & 99 \\
\hline Mississippi & Brainerd & $6 / 23 / 2015$ & 46.34847 & -94.20721 & 22.7 & 7.9 & -5 & 590 & 5900 & 99 \\
\hline Mississippi & Monticello & $6 / 22 / 2015$ & 45.294468 & -93.757178 & 25.2 & 8.2 & -5 & 170 & 1700 & 97 \\
\hline Mississippi & Red Wing & $6 / 22 / 2015$ & 44.562502 & -92.461088 & 23.9 & 8.4 & -5 & 1500 & 3600 & 96 \\
\hline Mississippi & Pettibone Pk, La Crosse & $6 / 22 / 2015$ & 43.812197 & -91.260732 & 24.7 & 8.4 & -6 & 290 & 1700 & 95 \\
\hline Mississippi & Dubuque & $6 / 22 / 2015$ & 42.495042 & -90.65702 & 23.2 & 8.1 & -6 & 470 & 2100 & 93 \\
\hline Mississippi & Muscatine & $6 / 21 / 2015$ & 41.419779 & -91.043757 & 24.4 & 7.9 & -5 & 870 & 3500 & 93 \\
\hline Mississippi & Canton & $6 / 21 / 2015$ & 40.139674 & -91.515404 & 23.9 & 8.0 & -5 & 1700 & 4700 & 90 \\
\hline
\end{tabular}


Table 1. Cont.

\begin{tabular}{|c|c|c|c|c|c|c|c|c|c|c|}
\hline River & Location & Date & Lat. & Long. & $\begin{array}{l}\text { Water Temp. } \\
\left({ }^{\circ} \mathrm{C}\right)\end{array}$ & $\mathrm{pH}$ & $\begin{array}{c}\text { Onset of } \\
\text { Freezing }\left({ }^{\circ} \mathrm{C}\right)\end{array}$ & $\begin{array}{l}\text { INPs Active at } \\
-7^{\circ} \mathrm{C}\left(\mathrm{mL}^{-1}\right)\end{array}$ & $\begin{array}{l}\text { INPs Active at } \\
-10^{\circ} \mathrm{C}\left(\mathrm{mL}^{-1}\right)\end{array}$ & $\begin{array}{l}\text { INPs Heat Labile } \\
\text { at }-10^{\circ} \mathrm{C}(\%)\end{array}$ \\
\hline Mississippi & Dam 25, Winfield & $6 / 21 / 2015$ & 39.0054 & -90.691467 & 24.0 & 8.0 & -5 & 2600 & 8700 & 99 \\
\hline Mississippi & Herculaneum & $6 / 17 / 2015$ & 38.258919 & -90.376007 & 22.8 & 7.7 & -4 & 2600 & 12,000 & 99 \\
\hline Mississippi & Cape Girardeau & $6 / 17 / 2015$ & 37.31516 & -89.512691 & 25.8 & 7.7 & -5 & 2600 & 12,000 & 97 \\
\hline Mississippi & Caruthersville & $6 / 17 / 2015$ & 36.232633 & -89.702174 & 28.0 & 8.6 & -5 & 210 & 720 & 76 \\
\hline Mississippi & Mud Island, Memphis & $6 / 18 / 2015$ & 35.18217 & -90.057939 & 28.6 & 7.4 & -5 & 150 & 470 & 92 \\
\hline Mississippi & Rosedale & $6 / 18 / 2015$ & 33.827979 & -91.053996 & 27.1 & 7.8 & -6 & 87 & 170 & 90 \\
\hline Mississippi & Mayersville & $6 / 18 / 2015$ & 32.917046 & -91.061286 & 26.8 & 7.7 & -5 & 1700 & 8700 & 96 \\
\hline Mississippi & Natchez & $6 / 18 / 2015$ & 31.558579 & -91.413607 & 26.6 & 7.7 & -5 & 1500 & 4700 & 93 \\
\hline
\end{tabular}


Table 2. Ice nucleating particles active at -7 and $-10{ }^{\circ} \mathrm{C}$ in $0.22 \mu \mathrm{m}$ filtrate. Up to three contiguous samples were combined for each test.

\begin{tabular}{lcc}
\hline \multicolumn{1}{c}{ Samples } & $\begin{array}{c}\text { INPs }<\mathbf{0 . 2 2} \boldsymbol{\mu m} \text { Active at } \\
-\mathbf{7}^{\circ} \mathbf{C ~ ( \% )}\end{array}$ & $\begin{array}{c}\text { INPs }<\mathbf{0 . 2 2} \boldsymbol{\mu m} \text { Active at } \\
\mathbf{- 1 0} \mathbf{~}^{\circ} \mathbf{C}(\mathbf{\%})\end{array}$ \\
\hline Sweetwater (Campsite, Bridge, Ore Road) & 100 & 97 \\
North Platte (Glendo Dam, Guernsey) & 31 & 32 \\
North Platte (SAREC, Lingle) & 44 & 24 \\
\hline
\end{tabular}
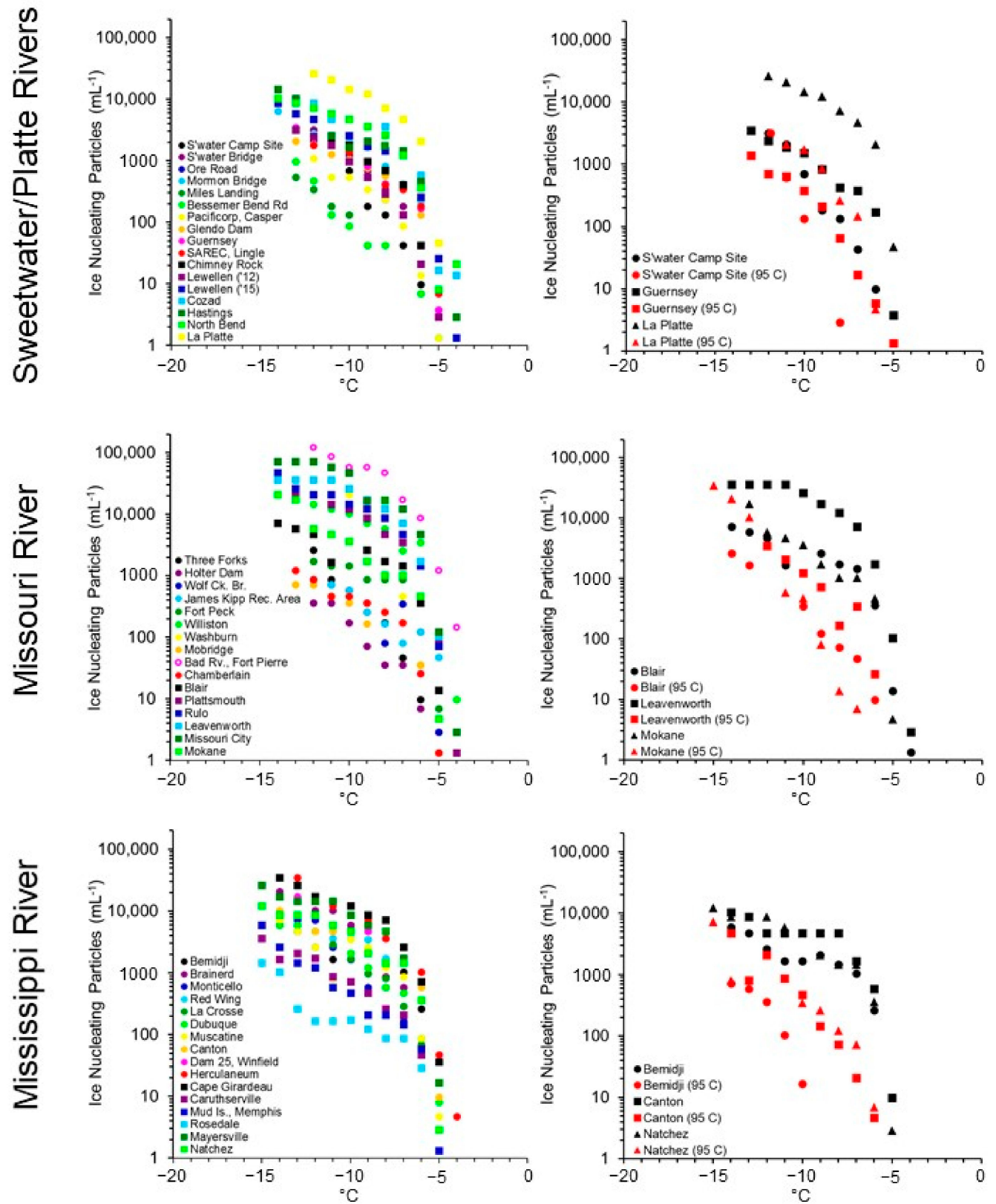

Figure 2. Full spectra of ice nucleating particle concentrations in the Sweetwater/Platte, Missouri and Mississippi Rivers. (Left) column figures show INP spectra in untreated water, while the (right) column figures give selected results (upper, middle, and lower reaches of each river system) for untreated and heat-treated $\left(95^{\circ} \mathrm{C}\right.$ for $20 \mathrm{~min}$ ) samples. 


\section{Discussion}

In this study, the concentrations of INPs in surface river water were much greater than that typically found in marine systems: median values at $-10{ }^{\circ} \mathrm{C}$ were around 2000 times that of seawater, which tends to be $\leq 1 \mathrm{~mL}^{-1}$ at $-10{ }^{\circ} \mathrm{C}[25,31]$ with occasionally higher transitory concentrations, probably associated with algal blooms [25]. The number of INPs was also highly variable, reflecting the relative contributions of a range of sources (Figure S2). The vast majority of INPs (66-99\%, median $93 \%$ ) were heat labile, suggesting a biological component. Indeed, the susceptibility of INPs to being denatured by $95^{\circ} \mathrm{C}$ generally increased with their concentration in the sample (Figure 3). It can also be seen that the warmer-temperature-active INPs are more heat sensitive and that the effect is lost around $-12{ }^{\circ} \mathrm{C}$ (Figure 2 and Figure S1); presumably, at colder temperatures INPs are a mix of heat-resistant organic and mineral INPs [12]. The size observations agree with previous work on freshwater INPs in Wales [31], marine INPs [17,20], precipitation [35-37], and recent studies showing that ice nucleating fungi and pollen release copious numbers of small (e.g., $<15 \mathrm{~nm}$ ) cell-free INPs [38-40].

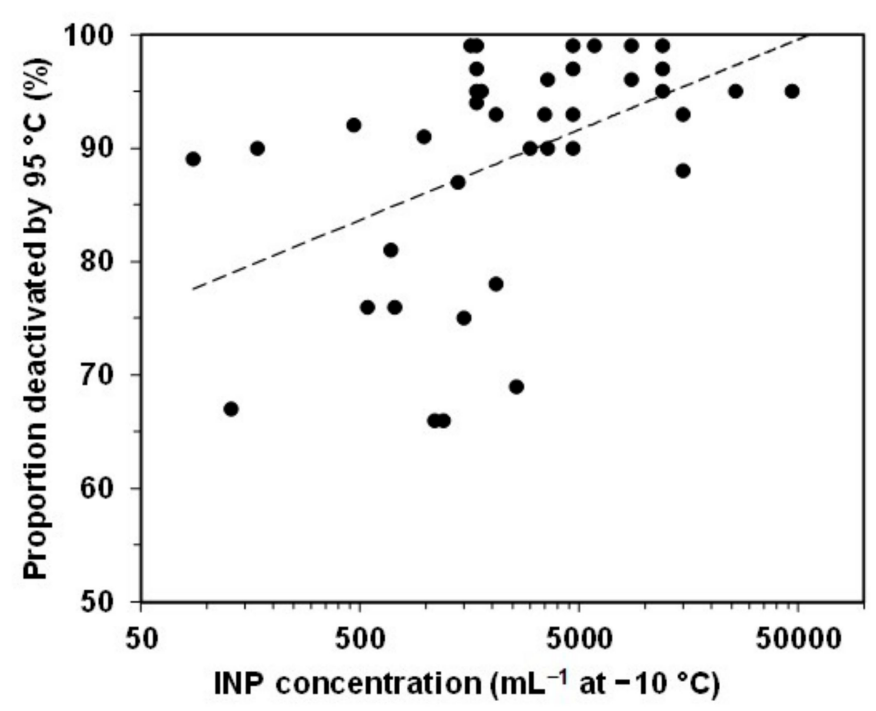

Figure 3. Relationship between INP concentration and heat susceptibility $\left(R^{2}=0.23\right)$.

Figure 1 highlights some of the geographic variation in the distribution and concentration of INPs. One point of interest is the confluence of the Mississippi River with its largest tributary, the Ohio. The two rivers are very different, with the turbid Mississippi living up to its moniker "The Big Muddy". There was a marked decrease ( $>15$-fold) in INP concentration below their junction (Figure 1 ). On the day of sampling, the discharge of the Mississippi upstream of the junction was $14,450 \mathrm{~m}^{3} \mathrm{~s}^{-1}$ with a suspended sediments loading of $1110 \mathrm{mg} \mathrm{L}^{-1}$ (monitored at Thebes; USGS National Water Information System, Site number 07022000), whereas that of the Ohio was only $4100 \mathrm{~m}^{3} \mathrm{~s}^{-1}$ (at Olmsted, USGS 03612600, no suspended sediments or turbidity data available at this or nearby stations). Hence, simple dilution of the Mississippi's INPs by a large influx of "cleaner" water from the Ohio did not cause the decrease. It, therefore, may have resulted from microbiological decomposition of organic INPs or from sedimentation due to a change in river chemistry. For example, at the time of sampling the $\mathrm{pH}$ of the Mississippi was 7.7-8.0, whereas in the Ohio it was 6.9. In non-alkaline water, divalent cations are more soluble and hence available to form flocs. An injection of $\mathrm{Mg}^{2+}$ and $\mathrm{Ca}^{2+}$ ions by the Ohio may have promoted flocculation and rapid settling of INPs downstream of the confluence.

By contrast, the large jump in INP concentration in the Missouri, from 1500 to 10,000, as it crossed from Montana into North Dakota (Figure 1), was likely due to large inflows of INP-rich water from the Yellowstone River just upstream of the Williston sampling point. During the afternoon of sampling, the Missouri's discharge was only $250 \mathrm{~m}^{3} \mathrm{~s}^{-1}$ (measured near Culbertson; USGS 06185500, 
no suspended sediments or turbidity data available) whereas the Yellowstone was three times higher (830 $\mathrm{m}^{3} \mathrm{~s}^{-1}$ and $155 \mathrm{mg} \mathrm{L}^{-1}$ suspended sediments, measured near Sidney, USGS 06329500). Interestingly, and as was also seen below the Mississippi/Ohio junction, INP concentrations then decreased as the Missouri flowed southeast through the Dakotas.

Although based on a limited number of observations, the level of sediment (a combination of upstream land use and rate of flow) in rivers may be directly related to the number of INPs. For example, the Bad River at Fort Pierre was sampled at its junction with the Missouri. This small tributary of the Missouri is noted for its very high silt levels, which was evident at the time of sampling. Accordingly, it had the greatest number of INPs of any sample: $17,000 \mathrm{~mL}^{-1}$ at $-7^{\circ} \mathrm{C}$ and $59,000 \mathrm{~mL}^{-1}$ at $-10^{\circ} \mathrm{C}$. Post precipitation run-off would produce a pulse of increased sediment inputs, while washing of foliage by rain would contribute additional INPs. In addition, the swollen river would wash additional areas of vegetation. The increased flow rate may also erode biofilms on river bed stones and pebbles, and stir up sediments on the river bed.

Freshwater could be a significant source of regional atmospheric INPs. Indeed, freshwater bacteria have even been found to dominate the bacterial microbiome of aerosols [41,42]. The same emission mechanism that operates in seawater-bubble bursting - would also facilitate freshwater INPs becoming airborne. Bubble bursting has been assessed to cover between 3-4\% of the ocean's surface at any one time [43]. This is likely to be greater for large freshwater bodies because the waves are smaller and occur with much greater frequency, and so break and foam more frequently [44]. In addition, film jet bubble bursting may be more extensive in freshwaters compared to marine due to the increased dissolved organic carbon content. This may be less significant in rivers during low flow rates, as demonstrated for the Rhine in Switzerland [32]. Using single particle aerosol time-of-flight mass spectrometry of aerosols generated from Lake Michigan water, Axson et al. [45] found a mass spectral fingerprint dominated by calcium carbonate but also with organic nitrogen markers consistent with the presence of organic material.

This initial study requires extension and refinement. Samples should be taken at different seasons, depths, and distances from the bank to build up a more detailed picture of freshwater INP dynamics and to assess the rate at which freshwater INPs become airborne and the factors, such as the influence of the surface microlayer, controlling it. Initial results from the Maumee River suggest that freshwater INPs do indeed become aerosolised [46]. Other rivers and, especially, large freshwater bodies such as lakes, reservoirs, glaciers, swamps, peat bogs, and other wetlands should also be analysed to see if these initial findings are broadly representative. For example, most samples in this study were taken from regions where agriculture predominates; other freshwater bodies may not reflect this anthropo-ecological context. As regards the nature of the INPs, at this stage we can only presume that they are macromolecules such as proteins; work is ongoing to characterize them. However, a testable hypothesis resulting from this initial work is that freshwater bodies are a significant repository of biological INPs, which are likely to vary seasonally and impact regionally on cloud ice formation, precipitation, and climate.

Supplementary Materials: The following are available online at http:/ /www.mdpi.com/2073-4433/9/8/307/s1, Figure S1: Full spectra of ice nucleating particle concentrations in the Sweetwater/Platte, Missouri, and Mississippi Rivers. Left column figures show INP spectra in untreated water, while the right column figures show all results for heat-treated samples $\left(95^{\circ} \mathrm{C}\right.$ for $\left.20 \mathrm{~min}\right)$, Figure S2: Sources of INPs in rivers.

Author Contributions: Conceptualization, B.F.M.; Formal analysis, T.C.J.H. and P.J.D.; Funding acquisition, B.F.M., T.C.J.H., and P.J.D.; Investigation, B.F.M.; Methodology, B.F.M.; Resources, T.C.J.H.; Writing-original draft, B.F.M. and T.C.J.H.; Writing—review and editing, B.F.M., T.C.J.H., and P.J.D.

Funding: This work was funded by National Science Foundation grant 1358495 (TH and PD). BM funded the rest from his Father's legacy.

Acknowledgments: We would particularly like to thank Gary Franc, deceased, at the University of Wyoming, for his generous support of the research and his advice. Further, we are grateful to Bob Baumgartner, manager of the University of Wyoming's James C. Hageman Sustainable Agriculture Research and Extension Centre (SAREC), for access to the centre and use of their laboratory. Also, we thank Arsineh Hecobian for producing Figure 1. 
Conflicts of Interest: The authors declare no conflict of interest.

\section{References}

1. Petters, M.D.; Wright, T.P. Revisiting ice nucleation from precipitation samples. Geophys. Res. Lett. 2015, 42, 8758-8766. [CrossRef]

2. Lohmann, U.; Feichter, J. Global indirect aerosol effects: A review. Atmos. Chem. Phys. 2005, 5, 715-737. [CrossRef]

3. DeMott, P.J.; Prenni, J.A.; Liu, X.; Kreidenweis, S.M.; Petters, M.D.; Twohy, C.H.; Richardson, M.S.; Eidhammer, T.; Rogers, D.C. Predicting global atmospheric ice nuclei distributions and their impacts on climate. Proc. Natl. Acad. Sci. USA 2010, 107, 11217-11222. [CrossRef] [PubMed]

4. Murray, B.J.; O'Sullivan, D.; Atkinson, J.D.; Webb, M. Ice nucleation by particles immersed in supercooled cloud droplets. Chem. Soc. Rev. 2012, 41, 6519-6554. [CrossRef] [PubMed]

5. Boucher, O.; Randall, D.; Artaxo, P.; Bretherton, C.; Feingold, G.; Forster, P.; Kerminen, V.-M.; Kondo, Y.; Liao, H.; Lohmann, U.; et al. Clouds and Aerosols. In Climate Change 2013: The Physical Science Basis. Contribution of Working Group I to the Fifth Assessment Report of the Intergovernmental Panel on Climate Change; Stocker, T.F., Qin, D., Plattner, G.-K., Tignor, M., Allen, S.K., Boschung, J., Nauels, A., Xia, Y., Bex, V., Midgley, P.M., Eds.; Cambridge University Press: Cambridge, UK; New York, NY, USA, 2013.

6. Hoose, C.; Möhler, O. Heterogeneous ice nucleation on atmospheric aerosols: A review of results from laboratory experiments. Atmos. Chem. Phys. 2012, 12, 9817-9854. [CrossRef]

7. Niemand, M.; Möhler, O.; Vogel, B.; Vogel, H.; Hoose, C.; Connolly, P.; Klein, H.; Bingemer, H.; DeMott, P.; Skrotzki, J.; et al. Parameterization of immersion freezing on mineral dust particles: An application in a regional scale model. J. Atmos. Sci. 2012, 69, 3077-3092. [CrossRef]

8. Boose, Y.; Welti, A.; Atkinson, J.; Ramelli, F.; Danielczok, A.; Bingemer, H.G.; Plötze, M.; Sierau, B.; Kanji, Z.A.; Lohmann, U. Heterogeneous ice nucleation on dust particles sourced from nine deserts worldwide-Part 1: Immersion freezing. Atmos. Chem. Phys. 2016, 16, 15075-15095. [CrossRef]

9. Conen, F.; Morris, C.E.; Leifeld, J.; Yakutin, M.V.; Alewell, C. Biological residues define the ice nucleation properties of soil dust. Atmos. Chem. Phys. 2011, 11, 9643-9648. [CrossRef]

10. O'Sullivan, D.; Murray, B.J.; Malkin, T.L.; Whale, T.F.; Umo, N.S.; Atkinson, J.D.; Price, H.C.; Baustian, K.J.; Browse, J.; Webb, M.E. Ice nucleation by fertile soil dusts: Relative importance of mineral and biogenic components. Atmos. Chem. Phys. 2014, 14, 1853-1867.

11. Tobo, Y.; DeMott, P.J.; Hill, T.C.J.; Prenni, A.J.; Swoboda-Colberg, N.G.; Franc, G.D.; Kreidenweis, S.M. Organic matter matters for ice nuclei of agricultural soil origin. Atmos. Chem. Phys. 2014, 14, 8521-8531. [CrossRef]

12. Hill, T.C.J.; DeMott, P.J.; Tobo, Y.; Fröhlich-Nowoisky, J.; Moffett, B.F.; Franc, G.D.; Kreidenweis, S.M. Sources of organic ice nucleating particles in soils. Atmos. Chem. Phys. 2016, 16, 7195-7211. [CrossRef]

13. Schnell, R.C.; Vali, G. Biogenic ice nuclei, Part I: Terrestrial and marine sources. J. Atmos. Sci. 1976, 33, 1554-1564. [CrossRef]

14. Vali, G.; Christensen, M.; Fresh, R.W.; Galyan, E.L.; Maki, L.R.; Schnell, R.C. Biogenic ice nuclei Part II, Bacterial sources. J. Atmos. Sci. 1976, 33, 1565-1570.

15. Burrows, S.M.; Hoose, C.; Pöschl, U.; Lawrence, M.G. Ice nuclei in marine air: Bioparticles or dust? Atmos. Chem. Phys. 2011, 13, 245-267. [CrossRef]

16. Wang, X.; Sultana, C.M.; Trueblood, J.; Hill, T.C.J.; Malfatti, F.; Lee, C.; Laskina, O.; Moore, K.A.; Beall, C.M.; McCluskey, C.S.; et al. Microbial control of sea spray aerosol composition: A tale of two blooms. ACS Cent. Sci. 2015, 1, 124-131. [CrossRef] [PubMed]

17. Wilson, T.W.; Ladino, L.A.; Alpert, P.A.; Breckels, M.N.; Brooks, I.M.; Browse, J.; Burrows, S.M.; Carslaw, K.S.; Huffman, J.A.; Judd, C.; et al. A marine biogenic source of atmospheric ice-nucleating particles. Nature 2015, 525, 234-238. [CrossRef] [PubMed]

18. DeMott, P.J.; Hill, T.C.J.; McCluskey, C.S.; Prather, K.A.; Collins, D.B.; Sullivan, R.C.; Ruppel, M.J.; Mason, R.H.; Irish, V.E.; Lee, T.; et al. Sea spray aerosol as a unique source of ice nucleating particles. Proc. Natl. Acad. Sci. USA 2016, 113, 5797-5803. [CrossRef] [PubMed] 
19. McCluskey, C.S.; Hill, T.C.J.; Malfatti, F.; Sultana, C.M.; Lee, C.; Santander, M.V.; Beall, C.M.; Moore, K.A.; Cornwell, G.C.; Collins, D.B.; et al. A dynamic link between ice nucleating particles released in nascent sea spray aerosol and oceanic biological activity during two mesocosm experiments. J. Atmos. Sci. 2017, 74, 151-166. [CrossRef]

20. McCluskey, C.S.; Hill, T.C.J.; Sultana, C.M.; Laskina, O.; Trueblood, J.; Santander, M.V.; Beall, C.M.; Michaud, J.M.; Kreidenweis, S.M.; Prather, K.A.; et al. A mesocosm double feature: Insights into the chemical make-up of marine ice nucleating particles. J. Atmos. Sci. 2018, 75, 2405-2423. [CrossRef]

21. Vergara-Temprado, J.; Miltenberger, A.K.; Furtado, K.; Grosvenor, D.P.; Shipway, B.J.; Hill, A.A.; Wilkinson, J.M.; Field, P.R.; Murray, B.J.; Carslaw, K.S. Strong control of Southern Ocean cloud reflectivity by ice-nucleating particles. P. Natl. Acad. Sci. 2018, 115, 2687-2692. [CrossRef] [PubMed]

22. Bigg, E.K. Ice nucleus concentrations in remote areas. J. Atmos. Sci. 1973, 30, 1153-1157. [CrossRef]

23. McCluskey, C.S.; Ovadnevaite, J.; Rinaldi, M.; Atkinson, J.; Belosi, F.; Ceburnis, D.; Salvatore, M.; Hill, T.C.J.; Lohmann, U.; Kanji, Z.A.; et al. Marine and terrestrial organic ice-nucleating particles in pristine marine to continentally influenced Northeast Atlantic air masses. J. Geophys. Res. Atmos. 2018, 123. [CrossRef]

24. Schnell, R.C.; Vali, G. Freezing nuclei in marine waters. Tellus 1975, 27, 321-323. [CrossRef]

25. Schnell, R. Ice nuclei in seawater, fog water and marine air off the coast of Nova Scotia: Summer 1975. J. Atmos. Sci. 1977, 34, 1299-1305. [CrossRef]

26. Engel, A.; Bange, H.W.; Cunliffe, M.; Burrows, S.M.; Friedrichs, G.; Galgani, L.; Herrmann, H.; Hertkorn, N.; Johnson, M.; Liss, P.S.; et al. The ocean's vital skin: Toward an integrated understanding of the sea surface microlayer. Front. Mar. Sci. 2017, 4, 165. [CrossRef]

27. Morris, C.E.; Sands, D.C.; Vinatzer, B.A.; Glaux, C.; Guilbaud, C.; Buffière, A.; Yan, S.; Dominguez, H.; Thompson, B.M. The life history of the plant pathogen Pseudomonas syringae is linked to the water cycle. Int. Soc. Microb. Ecol. 2008, 2, 321-334. [CrossRef] [PubMed]

28. Morris, C.E.; Sands, D.C.; Vanneste, J.L.; Montarry, J.; Oakley, B.; Guilbaud, C.; Glaux, C. Inferring the evolutionary history of the plant pathogen Pseudomonas syringae from its biogeography in headwaters of rivers in North America, Europe, and New Zealand. Am. Soc. Microbol. 2010, 1, 1-11. [CrossRef] [PubMed]

29. D'souza, N.A.; Kawarasaki, Y.; Gantz, J.D.; Lee, R.D., Jr.; Beall, B.F.N.; Shtarkman, Y.M.; Koçer, Z.A.; Rogers, S.O.; Wildschutte, H.; Bullerjahn, G.S.; et al. Diatom assemblages promote ice formation in large lakes. Int. Soc. Microb. Ecol. 2013, 7, 1632-1640. [CrossRef] [PubMed]

30. Pietsch, R.B.; David, R.F.; Marr, L.C.; Vinatzer, B.; Schmale, D.G., III. Aerosolization of two strains (Ice+ and Ice-) of Pseudomonas syringae in a collision nebulizer at different temperatures. Aerosol Sci. Technol. 2015, 49, 159-166. [CrossRef]

31. Moffett, B.F. Fresh water ice nuclei. Fundam. Appl. Limnol. 2016, 188, 19-23. [CrossRef]

32. Larsen, J.A.; Conen, F.; Alewell, C. Export of ice nucleating particles from a watershed. R. Soc. Open Sci. 2017, 4, 170213. [CrossRef] [PubMed]

33. Hill, T.C.J.; Georgakopoulos, D.G.; DeMott, P.J.; Stump, W.L.; Franc, G.D. Measurement of ice nucleation-active bacteria on plants and in precipitation by quantitative PCR. Appl. Environ. Microbiol. 2014, 80, 256-1267. [CrossRef] [PubMed]

34. Vali, G. Quantitative evaluation of experimental results on the heterogeneous freezing nucleation of supercooled liquids. J. Atmos. Sci. 1971, 28, 402-409. [CrossRef]

35. Vali, G. Sizes of atmospheric ice nuclei. Nature 1966, 212, 384-385. [CrossRef]

36. Rangel-Alvarado, R.B.; Nazarenko, Y.; Ariya, P.A. Snow-borne nanosized particles: Abundance, distribution, composition, and significance in ice nucleation processes. J. Geophys. Res. Atmos. 2015, 120, 11760-11774. [CrossRef]

37. Šantl-Temkiv, T.; Sahyoun, M.; Finster, K.; Hartmann, S.; Augustin, S.; Stratmann, F.; Wex, H.; Clauss, T.; Nielsen, N.W.; Sørensen, J.H.; et al. Characterization of airborne ice-nucleation-active bacteria and bacterial fragments. Atmos. Environ. 2015, 109, 105-117. [CrossRef]

38. Fröhlich-Nowoisky, J.; Hill, T.C.J.; Pummer, B.G.; Yordanova, P.; Franc, G.D.; Pöschl, U. Ice nucleation activity in the widespread soil fungus Mortierella alpina. Biogeosciences 2015, 12, 1057-1071. [CrossRef]

39. Pummer, B.G.; Budke, C.; Augustin-Bauditz, S.; Niedermeier, D.; Felgitsch, L.; Kampf, C.J.; Huber, R.G.; Liedl, K.R.; Loerting, T.; Moschen, T.; et al. Ice nucleation by water-soluble macromolecules. Atmos. Chem. Phys. 2015, 15, 4077-4091. [CrossRef] 
40. O'Sullivan, D.; Murray, B.J.; Ross, J.; Webb, M.E. The adsorption of fungal ice-nucleating proteins on mineral dusts: A terrestrial reservoir of atmospheric ice-nucleating particles. Atmos. Chem. Phys. 2016, 16, 7879-7887.

41. DeLeon-Rodriguez, N.; Lathem, T.L.; Rodriguez-R, L.M.; Barazesh, J.M.; Anderson, B.E.; Beyersdorf, A.J.; Ziemba, L.D.; Bergin, M.; Nenes, A.; Konstantinidis, K.T. Microbiome of the upper troposphere: Species composition and prevalence, effects of tropical storms, and atmospheric implications. Proc. Natl. Acad. Sci. USA 2013, 110, 2575-2580. [CrossRef] [PubMed]

42. Maki, T.; Hara, K.; Iwata, A.; Lee, K.C.; Kawai, K.; Kai, K.; Kobayashi, F.; Pointing, S.B.; Archer, S.; Hasegawa, H.; et al. Variations in airborne bacterial communities at high altitudes over the Noto Peninsula (Japan) in response to Asian dust events. Atmos. Chem. Phys. 2017, 17, 11877-11897. [CrossRef]

43. Pruppacher, H.R.; Klett, J.D. Microphysics of Clouds and Precipitation; Kluwer Academic Publishers: Dordrecht, The Netherlands, 1997.

44. Leifer, I.; Caulliez, G.; de Leeuw, G. Bubbles generated from wind-steepened breaking waves: 2. Bubble plumes, bubbles, and wave characteristics. J. Geophys. Res. Oceans 2006, 111, C06021. [CrossRef]

45. Axson, J.L.; May, N.W.; Coloón-Bernal, I.D.; Pratt, K.A.; Ault, A.P. Lake spray aerosol: A chemical signature from individual ambient particles. Environ. Sci. Technol. 2016, 50, 9835-9845. [CrossRef] [PubMed]

46. Knackstedt, K.A.; Moffett, B.F.; Hartmann, S.; Wex, H.; Hill, T.; Glasgo, E.; Reitz, L.; Augustiin-Bauditz, S.; Deustcher, W.H.; Beall, B.; et al. A terrestrial origin for abundant riverine nanoscale ice-nucleating particles. Environ. Sci. Technol. 2018. submitted.

(C) 2018 by the authors. Licensee MDPI, Basel, Switzerland. This article is an open access article distributed under the terms and conditions of the Creative Commons Attribution (CC BY) license (http:/ / creativecommons.org/licenses/by/4.0/). 